\title{
摩擦帯電評価システムの開発
}

（第 5 報）試験片の大きさ及び周辺の金属等の帯電圧及び減衰速度に及ぼす影響

$\begin{array}{ccccc}\text { 鐘紡(秼合繊研究所 } & \text { 松 } & \text { 井 } & \text { 雅 } & \text { 男(会員) } \\ \text { 鐘紡(侏開発研究所 } & \text { 柏 } & \text { 村 } & \text { 隆 } & \text { 光 } \\ \text { " } & \text { 岡 } & \text { 本 } & \text { 種 } & \text { 男 }\end{array}$

\section{Development of A New Frictional Static Charge Evaluation System \\ Part 5: A Study on the Influence of Testpiece-Size and \\ Surrounding Metalic Substance onto the Frictional \\ Charge (Voltage) and Decay Rate}

\author{
Masao Matsui*, Kazuo Okamoto** and Takamitsu Kashiwamura** \\ *Research Center for Synthetic Fibers, Kanebo, Ltd, Kanebo-cho, Hofu \\ ${ }^{* *}$ Research and Development Center, Kanebo, Ltd, Miyakojima, Osaka
}

\begin{abstract}
It was proved, in part 1 and 2, that the reproducibility and accuracy of newly developed KANEBO SYSTEM (KBS) are better than those of Rotary Static Tester and Faraday's Cage Method described in JIS L 1094 (1980).

The experiments to see the influence of testpiece-size and surrounding metalic substance onto frictional charge (voltage) and decay rate of fabrics was carried out. And, following facts have been found : (1) Tha voltage of nonantistatic and antistatic fabrics made of mix-spun antistatic fibers increase with the increase of the testniece-size, besides the voltage of Electric Conductive Fiber (ECF) contained antistatic fabrics do not change with the increase of testpiece size. (2) The decay rate of antistatic fabrics made of mix-spun antistatic fibers decrease with increase of testpiece size, besides the decay rate of the ECF contained antistatic fabrics do not change with the increase of the testpiece size. (3) The optimum size of testpiece may be 7 to $10 \mathrm{~cm}$ in diameter from the viewpoint of accuracy and easy operation.

(Received July 17, 1989)
\end{abstract}

\section{1. 序 論}

筆者等は, 制電性繊維, 導電性繊維及びその応用 製品の開発に当たり, 従来の各種制電性測定法が正 確さ, 再現性, 及び取り扱いやすさ等の点で極めて 不満足なあのであることを痛感し, 新しい方式の 「鐘紡摩擦帯電圧評価システム」を開発した. 鐘紡シ ステムは摩擦帯電圧とその減衰曲線を自記記録する

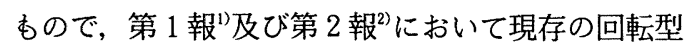

摩擦帯電圧測定器及びファラデーケージによる摩擦 帯電電荷密度測定法と正確さ, 再現性, 個人差など を比較し, 鐘紡法がそれら既存法よりあ優れている ことを確認した。なお，編織物の制電性（帯電性） の測定法は1980年 JIS L 1094（1980）として初めて 制定されたが, 最近見直し作業が行われ, 改訂版 JIS L 1094（1988）が1988年 8 月に刊行された. 新 JIS では従来参考法であった上記電荷密度測定法が 正式規格となり,さらに鐘紡法が新しく参考法とし 
て記載されている.

一般に電位 (電圧) $V$ と電気量 (電荷) $Q$ とは $Q$ $=C V$ という関係にあり, 両者は静電容量 $C$ を介し て相互に換算可能である. 帯電圧測定法は自然放電 （漏洩）により減衰する状況をリアルタイムで容易 に連続測定できるという大きなメリットがあり, 制 電剂の混合紡系や後加工による制電製品の評価に は, 不可欠である. 摩擦帯電圧とその減衰を測定す る鐘紡システムは, すべての制電品 (導電系混用品, 制電剂混合紡系, 制電後加工) の総合的評価が可能 という大きな特長を有する。 しかし, 帯電圧は試験 片の静電 (浮遊) 容量 $C$, 即ち, 試験片の大きさ, 周 辺物体の大きさと距離等によってかなり変わるの で，それらの影響を知っておく必要がある.

本報告は, 試料片の大きさ, 周辺物体等が鐘紡法 における摩擦帯電圧及びその減衰速度に及ぼす影響 についての検討結果を述べる.

\section{2. 実験方法}

測定装置一鐘紡システム KBS- 2 型（改良型）を 用いた。試料は摩擦台上で手動摩擦し, そのまま摩擦台と一体で検出器前に移動 した後, 摩擦台を下方へ剝離する. 剝離 直後の摩擦帯電圧 (最大值) 及び減衰曲 線が自記記録される。詳細は第 3 報3参 照.

金属製試料ホルダーの空（試料取付用 の円孔）の直径を $4 \mathrm{~cm}, 7 \mathrm{~cm}, 10 \mathrm{~cm}$, $13 \mathrm{~cm}, 16 \mathrm{~cm}$ と変え, それに対応して 摩擦台の直径を悹直径 $-2 \mathrm{~mm}$, さらに 較正用電極の直径を空直径 $-1 \mathrm{~cm}$ ( 3 $\mathrm{cm}, 6 \mathrm{~cm}, 9 \mathrm{~cm}, 12 \mathrm{~cm}, 15 \mathrm{~cm})$ と変 え, 帯電圧 (最大值) や減衰速度への試 験片サイズの影響を調查する．この他の 若干の基礎実験は KBS- 1 型（第 1 報参 照)を用いた。

試 料一表 1 に示す 6 種の試料, 即ち, 非制電 のポリエステル編織物 (B), 導電糸混用 品 3 種 (B 10, B 20, C), 制電ポリエス テル交織織物 2 種（A，A 2 ）を用いた.

試料は充分に洗濯, 水洗し, 活性剂等 を完全に取り除いた後, 充分調湿して測 定する．洗濯及び調湿条件は第 1 報と同 じ.

摩擦布及び摩擦回数一ウール添付白布 (JIS L
Table 1. Samples

\begin{tabular}{|c|c|}
\hline Sample & Material and Construction \\
\hline A & $\begin{array}{l}\text { Twill, Warp; Textured polyester filament. } \\
\text { Filler; Textured antistatic polyester filament }\end{array}$ \\
\hline A 2 & $\begin{array}{l}\text { Taffeta, Warp; polyester filament, } \\
\text { Filler; Antistatic polyester "Soielise-P" } \\
\text { filament (Kanebo) }\end{array}$ \\
\hline B & Knitted fabric, Polyester textured filament \\
\hline $\mathrm{B} 10$ & $\begin{array}{l}\text { Knitted fabric, Polyester and ECF "Belltron" } \\
\text { (Kanebo), ECF interval } 10 \mathrm{~mm}\end{array}$ \\
\hline $\mathrm{B} 20$ & $\begin{array}{l}\text { Knitted fabric, Polyester and ECF "Belltron, } \\
\text { ECF interval } 20 \mathrm{~mm}\end{array}$ \\
\hline $\mathrm{C}$ & $\begin{array}{l}\text { Twill, Warp and filler; Polyester/cotton = } \\
65 / 35 \text { blend-spun yarn, ECF "Belltron" is } \\
\text { mixed in warp, interval } 20 \mathrm{~mm}\end{array}$ \\
\hline
\end{tabular}

ECF ; Electric Conductive Fiber

0803）を同様に洗濯，調湿して使用，摩 擦回数は 12 回.

温湿度一 $20^{\circ} \mathrm{C}, 40 \% \mathrm{RH}$

測定繰り返し回数一それぞれの測定は同一試料片 について原則として 5 回繰り返し，その 平均值及び変動率を求める.

\section{1 結果及び考察}

図 1 に測定系の制電浮遊容量を示す. 浮遊容量 $C$ は, 検出器/試料片間の $C 1$, 背後板/試料片間の $C$ 2 , 及びホルダー/試験片間の $C 3$ の合計 $C 1+C 2$ $+C 3$ である. $C 1 \sim C 3$ の影響を調査すること及び 若干の基礎的検討を行った。

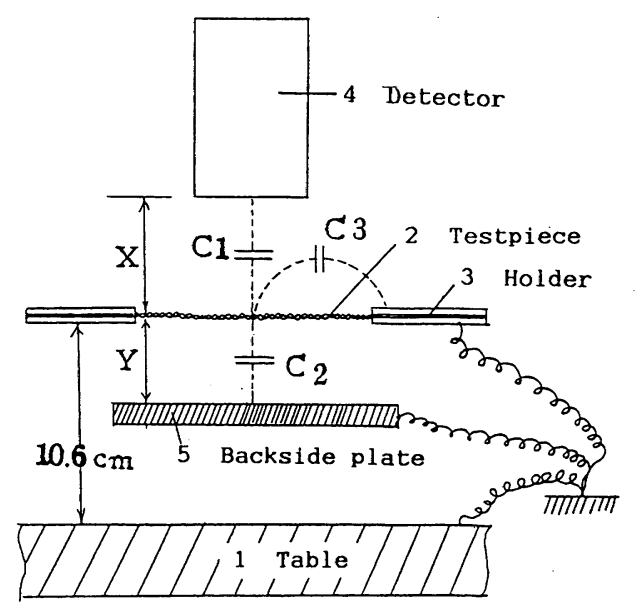

Fig. 1 Electric Capacity of the Measuring System 


\section{1 .1 検出器/試験片間距離の影響}

試料 $C$ を用い, 試験片之静電気検出器間の距離 (X) を $2 \mathrm{~cm}$ から $10 \mathrm{~cm}$ の範囲で $1 \mathrm{~cm}$ きざみで変 化させ, 摩擦帯電圧を測定した。測定器は KBS-1 型, ホルダー(3)の円孔 (空) は $70 \mathrm{~mm}$, 検出器(4)は, 回転セクター型で回転子の直径 $28 \mathrm{~cm}$, 金属保護筒 の外径は $32 \mathrm{~mm}$ である.

図 2 に摩擦帯電圧の検出器/試験片間距離依存性 を示す. 図に見るように, 帯電圧は距離 $X$ が $3 \sim 4$ $\mathrm{cm}$ で最大となり, それ以上距離が大きくなると 徐々に低下する. 静電容量 $C 1$ は距離 $X$ に逆比例的 と思われ, 距離の増大で帯電圧は増大し, $X$ が非常 に大きい領域では容量 $C 1$ が $C 2$ や $C 3$ と比べて無 視できるほど小さくなり, 距離依存性が消失すると 予想される. 図 2 では, 距離 $X$ が $3 \sim 5 \mathrm{~cm}$ で上記 の距離依存性が消失したと見なされるが，それ以上 の領域での帯電圧の低下理由は不明である。この現 象は, 試料片内に電位分布があり中央付近が高く周 辺が低いこと及び検出器の感度が中心部が高く, そ の検出角度がある程度狭いと仮定すれば説明されよ う. 即ち, 検出器が近いときは試料中心付近を主と して検出するため, 高い帯電圧が観測され, 距離が 大きくなると周辺の低電位部をも検知し, 平均して やや低い帯電圧が観測されるのである.

いずれにせよ, 金属製試料ホルダーで空が直径 7 $\mathrm{cm}$ のときは, 検出器距離 $3 \sim 5 \mathrm{~cm}$ で最高感度を 示し, かつ帯電圧の距離依存性がほとんどないか ら, 我々は実用的見地から検出器距離として $5 \mathrm{~cm}$ を選んだ。

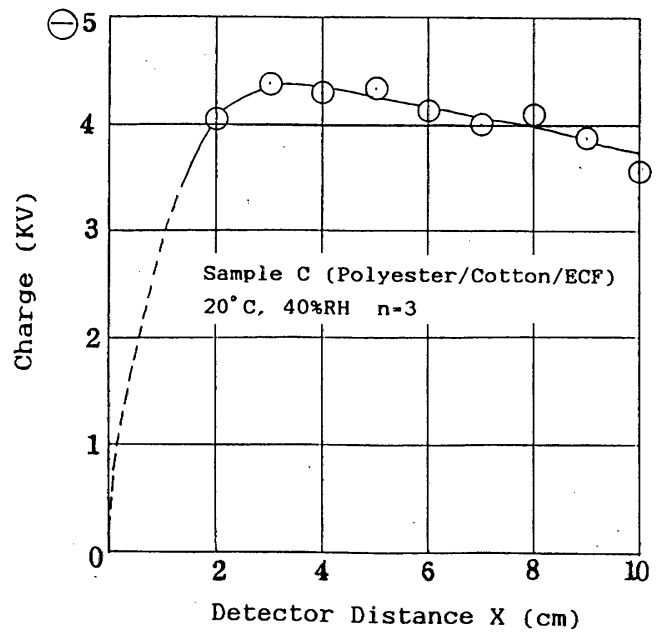

Fig. 2 Change of Frictiongl Charge by the Distance between Detector and Testpiece

\subsection{2 背後板/試験片距離の影響}

帯電圧の減衰が極めて遅い試料 $B$ を用い, KBS1 型機で摩擦帯電圧を測定しながら金属製の背後板 (5) 試験片の距離 $Y$ を種々変えて, 試料電位の距 離依存性を調べた。結果を図 3 に示す. 距離 $Y$ が 2 $\mathrm{cm}$ 以下では電位は急激に変わるが, 距離 $3 \mathrm{~cm}$ 以 上ではその変化はわずかとなり $8 \mathrm{~cm}$ 以上で, 距離 依存性がほぼ消失する. 鐘紡システムでは試験片と 摩擦テーブルの台板(1)との距離約 $10 \mathrm{~cm}$ であるが, それが充分大きいといえる。

電位が $1 / 2$ になる背後板距離は約 $0.75 \mathrm{~cm}$ である. このときの静電容量 $C 2$ は, (1)式の平行板コンデン サーの静電容量の式で計算し, 距離 $d=0.75 \mathrm{~cm}$, 空 の有効面積を $28 \mathrm{~cm}^{2}$ （直径 $6 \mathrm{~cm}$ ) と仮定して, 3.3 $\mathrm{pF}$ (ピコファラド) となる.

静電容量 $C$ (ファラド $)=8.76 \times 10^{-14} \mathrm{~S} / d$

ここで $d$; 極板間距離 $\mathrm{cm}, S$; 極板面積 $\mathrm{cm}^{2}$ 電位が $1 / 2$ になることは, 静電容量が 2 倍になっ たことを意味するから， $C 1+C 3=C 2=3.3 \mathrm{pF}$ と近似し得る.

\subsection{3 試験片寸法の帯電圧への影響}

前述のように鐘紡システム（KBS-1 型）におい ては標準のホルダー孔 (空) は直径 $7 \mathrm{~cm}$ であり, ホ ルダー (接地金属)/試料片間の静電浮遊容量 $C$ が最 あ大きい，KBS- 2 型を用いホルダー孔の直径を 4 $\mathrm{cm}, 7 \mathrm{~cm}, 10 \mathrm{~cm}, 13 \mathrm{~cm}, 16 \mathrm{~cm}$ と変え（それに 対応して摩擦台, 較正電極の大きさ及び試料/検出 器間距離む大きくなる), 摩擦帯電圧とその減衰曲 線を測定した。帯電・放電曲線の代表例を図 4 及び 図 5 に示し, 全試料の帯電圧（摩擦直後の最大值）

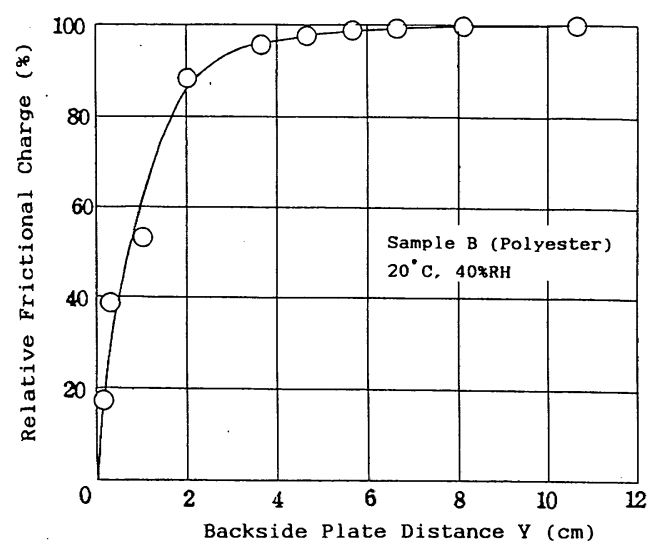

Fig. 3 Change of Frictional Charge by the Distance between Backside Plate and Testpiece 


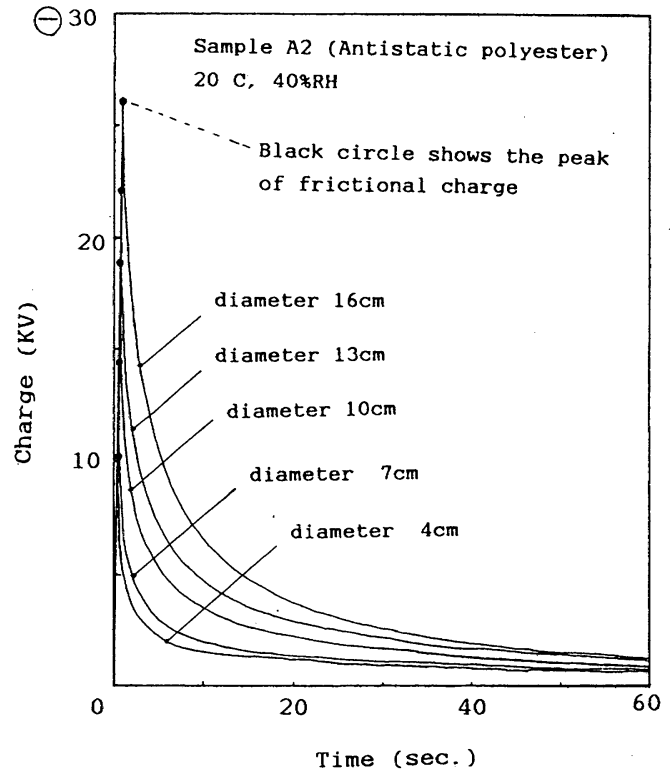

Fig. 4 Change of Frictional Charge and Decay Curve by the Testpiece Size

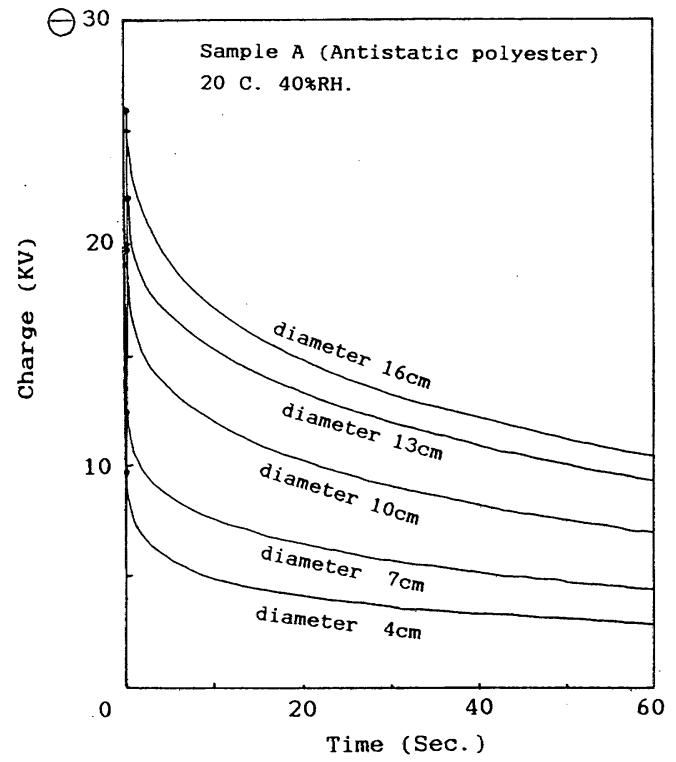

Fig. 5 Change of Frictional Charge and Decay Curve by the Testpiece Size

の試験片サイズ依存性を表 2 及び図 6 に示す. 表 2 及び図 6 から次のことが明らかである.

（1）非制電試料 B 及び制電剂混合紡系型の制電 試料 A, A 2 の帯電圧は, 試験片サイズ（直径） の増大とともに，直線的に増大する.

(2) 一方, 導電糸 (ECF) が混用された制電性試 料 B 10, B 20, C の帯電圧は試験片サイズの大

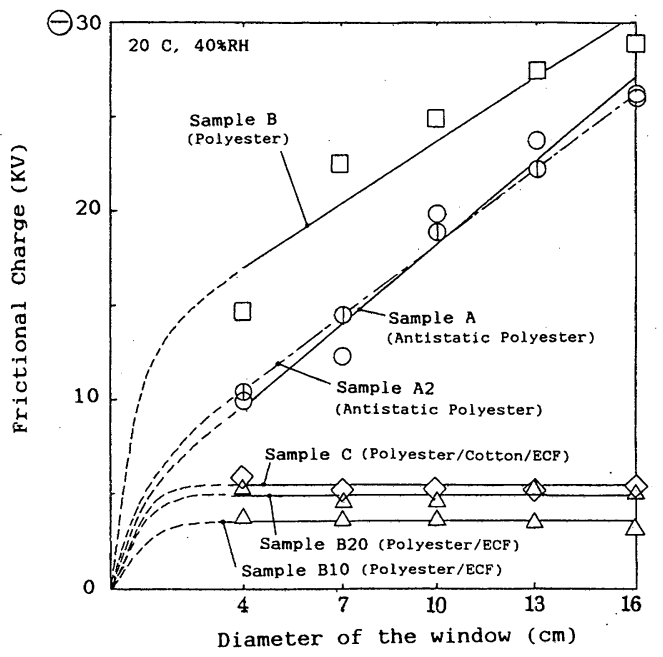

Fig. 6 Testpiece-size Dependence of Frictional Charge

きさに無関係にほぼ一定である.

即ち, 導電系を含む試料と含まない試料とは, 全 く異なる挙動を示す，導電糸を含まない試料では, 試料が大きくなると試料の金属製のホルダーからの 平均距離が大きくなり浮遊容量 $C 2$ (単位面積当た り）が減少する. その結果, 前述の $Q=C V$ の式に従 って電位 $V$ が高くなると推定される.

一方, 導電系を含む試料では, 帯電圧の試験片サ イズ依存性がほとんど見られない理由は次のように 説明されよう。即ち,これらの編織物には導電糸 （連続フィラメント）が一定間隔で交編織されてお り, 金属ホルダー部において導電系は電気的に接地 されていると推定される。，その結果，試料の接地導 体からの平均距離は導電系間隔で一義的に決まり, 試験片の大きさに無関係となる。試料 B 20 と C と は導電糸間隔がともに $2 \mathrm{~cm}$ で，母体緘維及び織構 造が異なるにもかかわらず，ほぼ同じ帯電圧を示し ている.このことは主として導電系間隔によって帯 電圧が決まるという上記説明を裏付けるものであ る.

導電糸が接地されていない場合（枠が絶縁されて いる場合）については次報で検討する予定である.

\section{1 .4 試料寸法の減衰速度への影響}

減衰速度は, 帯電圧が摩擦直後の最大值から, そ の1/2に減衰するまでの半減期 (HDT; Half Decay Time）で表すことが多い. しかし減衰の遅いものは 半減期では表現困難なので, 一定時間（ここでは 1 分間) 後の帯電圧 (電荷でも同じ) の残留率 (ROC; 
Table 2. Change of Frictional Charge by Testpiece Size

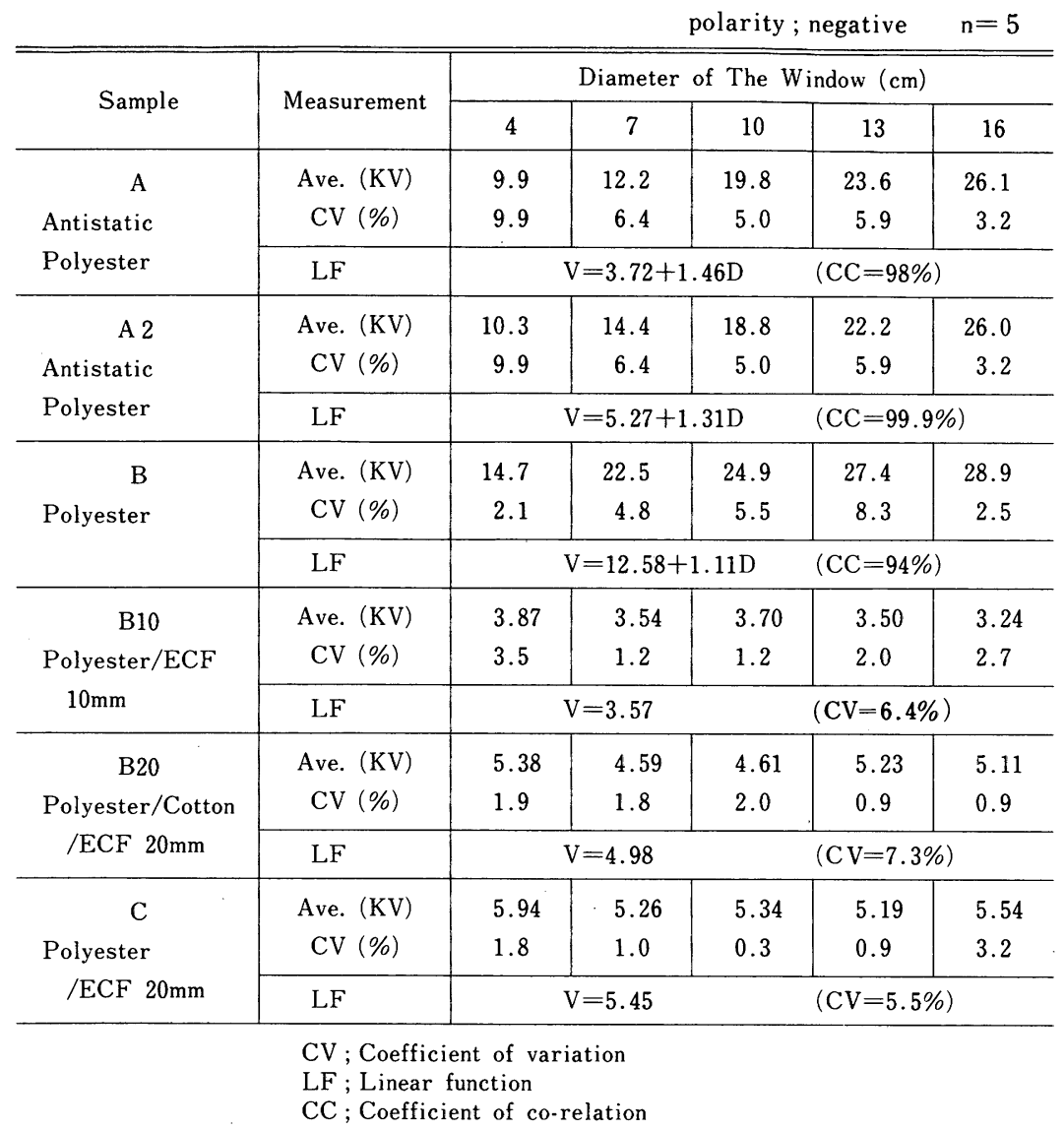

Remains of Charge), 即ち, 最大值に対する比率 を併用する.

各試料の半減期及び電荷残留率の試験片寸法依存 性を表 3 及び図 7 〜 9 示す. 試料 B, B 10, B 20 は減衰が遅く半減期では表現できない，減衰のやや 遅い試料 $\mathrm{A}$, 減衰の早い A 2 及び C の半減期の試 験片寸法依存性を図 7 に示す．図 7 及び表 3 に見る ように，導電糸を含む試料 C (綿/ポリエステル)で は半減期の寸法依存性が見られないが, 練込制電系 A 及び A 2 では試験片寸法とともに半減期が顕著 に（ほぼ直線的に）増大する。

一般に, 電気容量 $C$ と電気抵抗 $R$ の回路の放電 速度を示す時定数（電圧が初期の0.368倍になる時 間，秒）は $R C$ で示される. 金属枠（空）が大きいほ ぞ，アースに対する試料片の見掛けの（平均的） $R$ が大きくなると思われ，その結果時定数及び半減期 が増大するのであろう. しかし導電糸混用品で導電 糸が接地されている場合は, $R$ む $C$ 導電糸間隔で 主として定まっており, 空寸法に無関係となるので

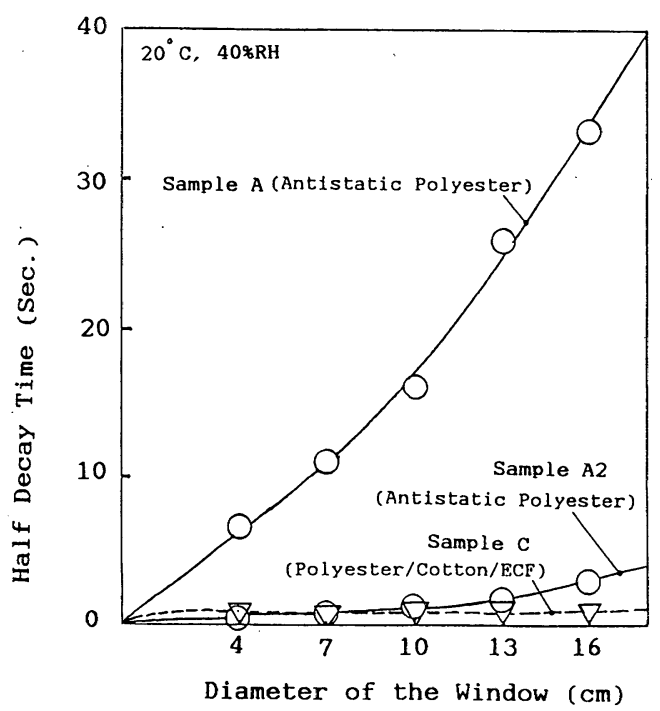

Fig. 7 Change of Decay Rate by Testpiece Size あろう。

今回の実験では同一試験片で測定を 5 回繰り返し 
Table 3. Change of Decay Rate by Testpiece Size

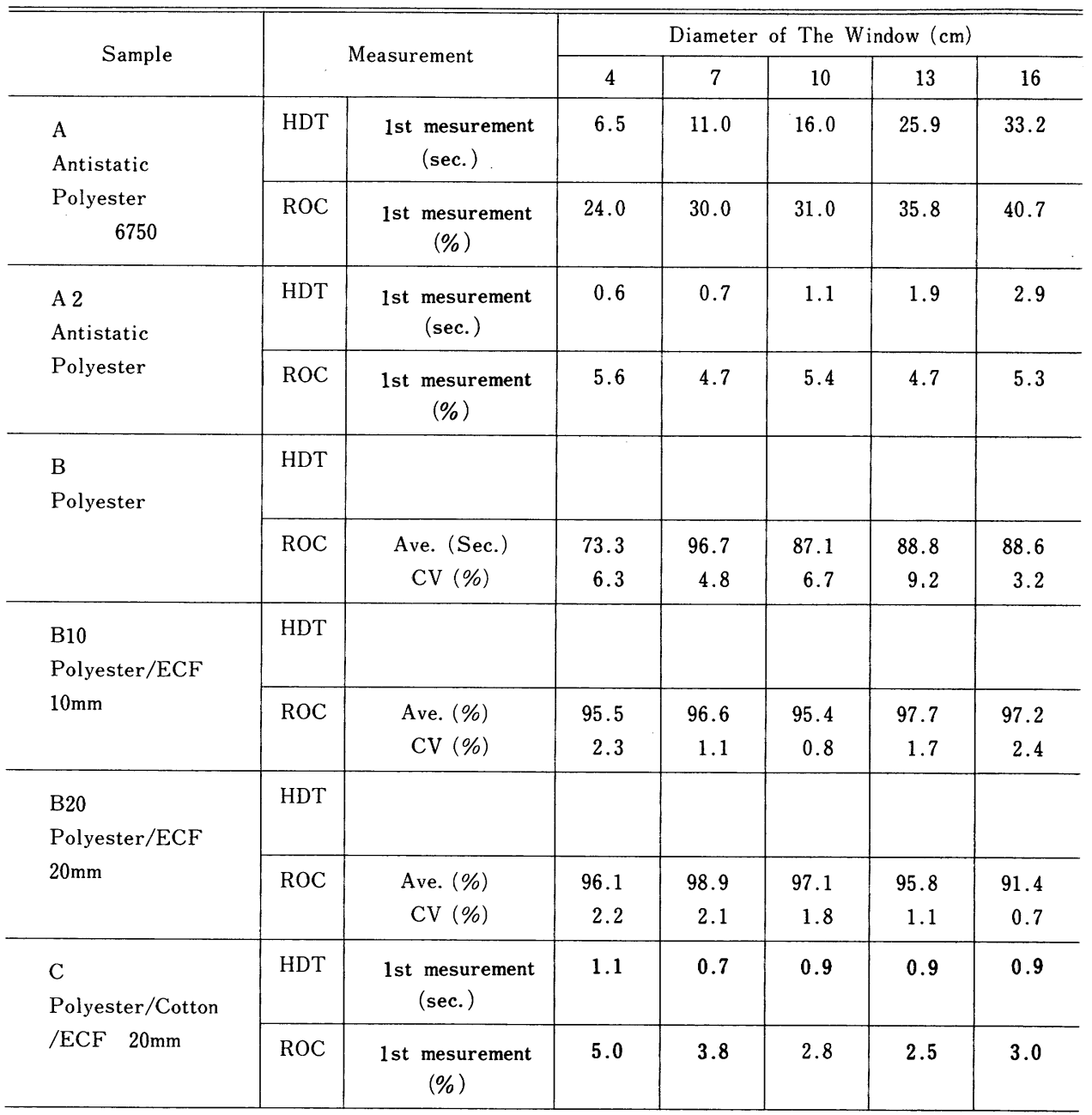

たが，減衰速度は測定の繰り返しによって少しずっ 低下する傾向が認められるために，5回の平均值で 示すのは適当でない. 図 8 に試料 A の半減期の測 定繰り返しによる変化を示す．かなりバラッキが大 きいが測定繰り返しにより半減期が増大している. 従って, 減衰性試料の減衰速度の測定は, 複数回の 測定值加ら回帰直線を求め, 測定回数 0 の点に外挿 して求めるのが良いかす知れない. しかし今回は 1 回目の測定值を用いた.このような減衰型 (漏洩型) 試料での摩擦帯電・放電の繰り返しによる減衰速度 低下は今回初めて気が付いたもので，その原因は不 明である. しかし我々は他の実験でむこの現象を確 認しており，かなり普遍的な現象と思われる.

\subsection{5 最適試験片サイズの検討}

前述のように, 摩擦帯電圧（最大値）及びその減 衰性は，試験片寸法によってかなり大幅に変わるこ
とがあり，最適寸法を選ぶ必要がある，選定に当た っては，1）実際の使用状態に近いこと，2）測定 の信頼性，3）測定操作の容易さ等を考慮する必要 がある. 現行 JIS の試料寸法を表 4 に示す.

摩擦帯電圧測定に関しては，実際の使用状態との 比較及び安定な摩擦の見地から JIS B 法の試験片サ イズは第 1 報に述べたようにあまりにあ小さい、サ イズ依存性のない導電糸混用品においても, 導電系 間隔が $12.5 \mathrm{~mm}$ 以上のものは，惫寸法 $25 \mathrm{~mm} \times 30$ $\mathrm{mm}$ の JIS B 法では評価が無意味である，導電糸間 隔が $20 \sim 30 \mathrm{~mm}$ の製品も実際に多く使用されて おり, 枠 (空) の幅又は直径は $40 \sim 60 \mathrm{~mm}$ 以上が 必要である. 逆に, サイズが大きすぎると測定操作 が困難で誤差も大きくなる傾向があり, 帯電圧す数 十 KV と高く較正も困難になる. 図6に見るように 鐘紡法において, 帯電压と悹直径はかなり良い直線 
Table 4. Testpiece Size of JIS L 1094 (1988)

\begin{tabular}{c|c|c}
\hline \hline \multicolumn{1}{c|}{ Method } & Testpiece Size & \multicolumn{1}{c}{ Window Size } \\
\hline A. Half Decay Time & $45 \mathrm{~mm} \times 45 \mathrm{~mm}$ & $32 \mathrm{~mm} \times 32 \mathrm{~mm}=10.2 \mathrm{~cm}^{2}$ \\
\hline B. Frictional Charge & $50 \mathrm{~mm} \times 80 \mathrm{~mm}$ & $\begin{array}{l}25 \mathrm{~mm} \times 30 \mathrm{~mm}=7.5 \mathrm{~cm}^{2} \\
\text { effective area } \\
15 \mathrm{~mm} \times 20 \mathrm{~mm}=3.0 \mathrm{~cm}^{2}\end{array}$ \\
\hline C. Charge Density & $25 \mathrm{~cm} \times 35 \mathrm{~cm}$ & $\begin{array}{l}\text { effective area } \\
25 \mathrm{~cm} \times 26 \mathrm{~cm}=650 \mathrm{~cm}^{2}\end{array}$ \\
\hline R1. Electric Resistance & $50 \mathrm{~mm} \times 80 \mathrm{~mm}$ & $\begin{array}{l}\text { effective area } \\
5 \mathrm{~cm} \times 5 \mathrm{~cm}=25 \mathrm{~cm}^{2}\end{array}$ \\
\hline $\begin{array}{l}\text { R2. Clinging Test } \\
\text { R3. Frictional Charge } \\
\text { and Decay Curve } \\
\begin{array}{l}\text { (Kanebo System) } \\
\text { effective area } \\
7.5 \mathrm{~cm} \times 20 \mathrm{~cm}=150 \mathrm{~cm}^{2}\end{array}\end{array}$ & $75 \mathrm{~mm} \times 230 \mathrm{~mm}$ \\
\hline
\end{tabular}

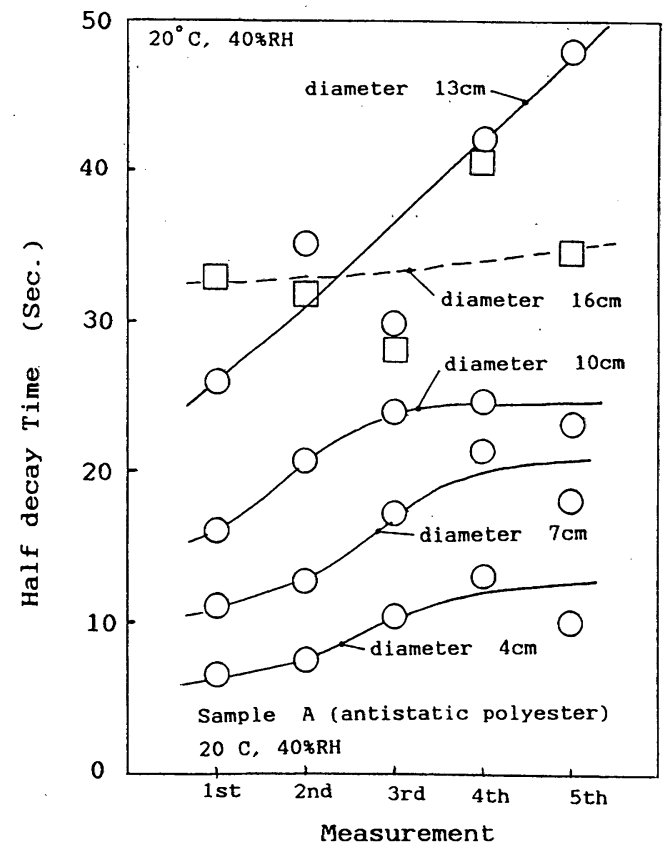

Fig. 8 Change of Decay Rate by Repeat of Measurement

関係にあるから，標準の直径 $7 \mathrm{~cm}$ のデータから， 直径があっと大きい場合の帯電圧む推定し得る.

減衰速度測定に関しては，実際との対応及び導電 系混用品評価の見地から上記と同じく空の幅又は直 径は $40 \sim 60 \mathrm{~mm}$ 以上が必要であり, JIS A 法の 32 $\mathrm{mm}$ は小さすぎる. 又, 小さすぎる試料では半减期 が短くなるので測定系の追随速度に問題を生じ誤差

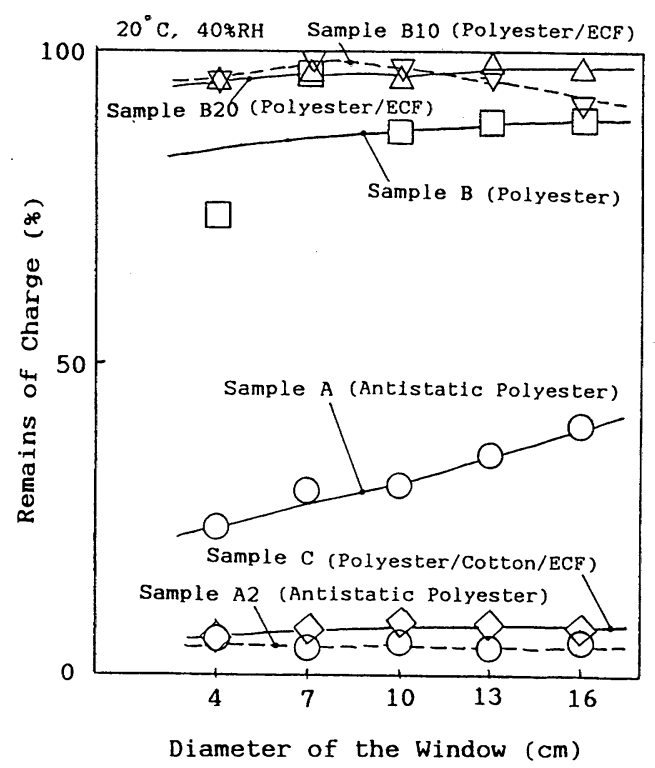

Fig. 9 Change of "Remains of Charge" by Testpiece Size

あ大きくなる恐れがある.

一方, JIS C 法 (電気量測定) では, 試験片寸法は $25 \mathrm{~cm} \times 35 \mathrm{~cm}$ と非常に大きい. そのため試料の洗 濯, 乾燥, 調湿, 保存などに非常に不便であり，し かむ測定操作が困難で, 第 2 報で述べたように誤差 あ大きい.

以上のように JIS A 法, B 法は試験片寸法があま りにも小さすぎ, JIS C 法では大きすぎる. 従って 筆者等は，信頼性の面から必要充分な大きさで，し 
かも操作性の面でできるだけ小さい範囲として, 悹 (枠) 直径 $7 \sim 10 \mathrm{~cm}$ 程度が最適と考えている.

\section{3. 結 論}

非制電品, 導電糸混用品, 制電剂練込品計 6 種の 試料について摩擦帯電圧及びその減衰速度に対する 試験片ホルダー (金属枠) の空直径を $4 \sim 16 \mathrm{~cm}$ に 変えてその影響を調查し次の結果を得た。

(1) 非制電品, 練込制電品の摩擦帯電圧は, 空の 直径の増大とともにほぼ直線的に増大する。こ れは試料の単位面積当たりの静電浮遊容量の減 少による電位上昇を示すものと思われる.

(2) 導電糸混用品の摩擦帯電圧は空の寸法に無関 係にほぼ一定である. 即ち, 導電系は金属ホル ダー部に接地されるため, 帯電圧は導電系間隔 によって一義的に定まり, 空枠の大きさの影響 は無視し得る.

(3) 練込制電糸の帯電圧の減衰の半減期は, 空直 径の増大とともにほぼ直線的に増大する。これ は試料全体の（平均的）電気抵抗 $R$ が増大する ためと思われる.

(4) 導電糸混用品の半減期は空直径に無関係に一 定である。これは，上記(2)と同じく導電糸の間
隔によって主として減衰特性を支配する因子 （静電容量 $C$ と抵抗 $R$ ） が定まるためと思われ る.

（5）摩擦帯電圧及びその減衰性の測定にとって, 試験片（空）寸法は大きな影響を与える，悹寸 法が小さすぎると誤差が大きく，信頼度が小さ い. 大きすぎても誤差が大きく, 操作にも不便 である.

必要充分でかつ最む小さい空寸法は直径 7 $10 \mathrm{~cm}$ であると考える.

(6) 本システムの標準型である空寸法直径 $7 \mathrm{~cm}$ においては, 検出器/試験片間距離 $X$ は $5 \mathrm{~cm}$ が適当であり, 背後板/試験片間距離 $Y$ は 10 $\mathrm{cm}$ で充分である.

\section{参考文献}

1）松井他;摩擦帯電評価システムの開発（第 1 報）開発した 装置の概要, 測定值及びバラッキの従来流との比較, 織機 誌, 40 No. $4(1987-4)$

2) 松井他;摩擦帯電評価システムの開発（第 2 報）開発した 装置の測定值個人差の従来法との比較及び 2,3 の基礎的 事項の検討, 瀻機誌, 40, No. $10(1987-10)$

3）松井他; 摩擦帯電評価システムの開発（第 2 報）摩擦後の 剝離方法及び測定前の電荷の隇衰の検討, 䋞機誌, 42, No. $4(1989-4)$

\section{投稿歓迎}

䄉維工学編集委員会では, 下記のような種類の原稿の投稿を歓迎します，学問的，技術 的知見, 経験などで, 公開できるものはできるだけ多く「糃維工学」誌上にご発表いただ き，会員の相互啓発，我国の学界，産業界の発展に寄与されることを希望します.

総説：提案, 意見, 批評等の論説及び研究, 技術, 経済などの総合的な記事

解説：織維工業分野に直接あるいは間接に関係す る最新の内外の技術, 重要トピックス等の 平易な解説記事

講義：系統的でまとまった知識を与える記事

資料：調査, 解説等の技術的に価値ある資料で, 他のどの種類にも該当しないもの

製品紹介：技術的に優れた製品の紹介

見 学 記: 学校, 研究所, 会社等の見学記録

座 談 会: 対談, てい談, 座談会の記事

その 他: 学校, 研究所, 会社等の見学記録, 対談,
てい談, 座談会及び委員会, 研究会等の報 告記事と記録

\section{投稿後の原稿の取扱い}

1. 原稿の採否, 分類等については綫維工学編集委員 会で決定します（依頼あるいは投稿された原稿は 専門分野の查読委員が査読し訂正を求めることが あります)。

2. 校正は原則として初校 1 回お願いします.

3. 抜刷は30部に限り進呈します.

4. 版権は本会に属します。 